\title{
The suitability of foreign language teaching in childhood according to the CLIL approach: The foreign language teachers' attitudes
}

Tilen Smajla

Elementary School Pier Paolo Vergerio Il Vecchio, Gimnazijski trg 7, 6000 Koper, Slovenia tilen.smajla@gmail.com

ARTICLE INFO

Article history

Received 17 February 2021

Revised 08 April 2021

Accepted 20 April 2021

Keywords

Attitudes

CLIL approach

early age

foreign language teacher

foreign language teaching

\begin{abstract}
This paper presents the results of a research into the foreign teachers attitudes towards the first foreign language (FL 1) teaching according to the CLIL approach. The first foreign language teachers (FL 1 teachers) should have carried out their FL 1 lessons using the CLIL approach. The results of the twelve interviews: teachers agree upon the importance of the education process of teachers-to-be, for any teacher working at an early level should have completed a BA in class teaching and should have acquired a degree in the methodology of early language teaching. Most teachers who used the CLIL approach in the first year of its introduction (school year 2014-2015), refrained from it in the second year, or only used some elements of the CLIL approach, for they felt that it was impossible to follow the guidelines of the "hard" CLIL. Consequently, they only used some elements or strategies of the CLIL approach, which some authors call "soft" CLIL. Although some teachers claimed to have encountered numerous obstacles in teaching according to CLIL, they nevertheless considered it to be a suitable approach in the FL 1 classroom and they feel that CLIL has contributed significantly to the learning outcomes.
\end{abstract}

This is an open access article under the CC-BY-SA license.

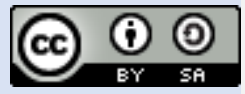

How to Cite: Smajla, T. (2021). The suitability of foreign language teaching in childhood according to the CLIL approach: The foreign language teachers' attitudes. English Language Teaching Educational Journal, 4(1), 1-14. doi.org/10.12928/eltej.v4i1.3702

\section{Introduction}

In the member states of the European Union, children start learning foreign languages at a very early age, for it was determined that early language learning has a positive impact on mother tongue proficiency and it increases motivation for learning foreign languages in the subsequent period (Čok, 2008; Lipavic Oštir \& Jazbec, 2010). In contrast, many parents and teachers expressed considerable concern over the possibility that too early exposure to a variety of languages might slow down children's cognitive development (Dagarin Fojkar \& Skubic, 2017, p. 87). The research, however, showed that bilingual children, for example, develop certain types of cognitive flexibility and metalinguistic consciousness earlier and to a greater extent than their monolingual peers (Cummins, 2000; King \& Mackey, 2007). According to foreign language teaching methodology, foreign language lessons should be continuously carried out using the "vertical approach" (early 
Vol. 4, No. 1, 2021, pp. 1-14

learning of the first foreign language, the second foreign language is introduced later) in parallel with the "horizontal approach", establishing different connections with children's mother tongue, other languages and other subjects (music class, art class, learning about the environment, etc.) (Lipavic Oštir \& Jazbec, 2010). Learning and teaching in the first educational period (EP 1) is specific, which is why these processes must be conducted in accordance with the principles for teaching young pupils. The school curriculum for the first foreign language (FL 1) at an early age (in the second and third grades of primary school) (Pevec Semec et al., 2013) emphasises the advantage of early FL 1 learning, as this stresses children's characteristics in this period, such as curiosity, the desire to learn, the need to communicate as well as the willingness and capability to imitate new and unfamiliar sounds (Pevec Semec et al., 2013, p. 6). The thesis briefly outlines how the CLIL approach was implemented in Slovenia on a statewide level for the first time and describes the circumstances of introducing foreign language lessons according to the CLIL approach.

Based on what was written in the aforementioned text we would like to highlight the valuable contribution of the efforts of FL teachers in their attempts to boost the learning outcomes of young foreign language learners, which is exactly what our research has concluded.

\subsection{The CLIL Approach}

The introduction mentions the CLIL approach, which was first recognized in 1995 in the Council Resolution of 31 March 1995 on improving and diversifying language learning and teaching within the education systems of the European Union. The CLIL approach is known under various names, such as language bath, language showers, integrated lessons, bilingual lessons, total or partial immersion, or - as stated in Lipavic Oštir et al., 2015 - non-language subject in a foreign language. During its development and implementation it has been compared and/or considered as a synonym to integrated thematic instruction (school model designed by Kovalik, see Kovalik \& Olsen, 1993), immersion (Lasagabaster \& Sierra, 2009), content-based instruction (Cenoz, 2015), task-based language teaching (Ortega, 2015), English for specific purpose (Yang, 2016; Taillefer, 2013; Tzoannopoulou, 2015) or bilingual education (Nikula, 2018). CLIL programmes are an approach to learn English or another foreign language by combining language and content subjects. In some contexts, CLIL is selective and this selection can be based on cognitive abilities or may also be linked to socio-economic backgrounds (Van Mensel et al., 2020). The integration of content and language is one of the main characteristics of the CLIL approach, as the relationship between these two elements is at the core of any implementation (Llinares \& Morton, 2017; Nikula et al., 2016). Karabassova (2018, p. 2) claimed that there is a "dichotomy of teaching the content subject and teaching the language instead of utilizing an integrated approach towards teaching". This dichotomy exists because most teacher education degrees are oriented either to language or to content, particularly in the case of secondary education. This problem arose because content teachers believed they should give priority to content (DaltonPuffer, 2011; Karabassova, 2018; Lo, 2019). Beliefs are essential to understand how each CLIL teacher conceptualises CLIL or her/his role as a teacher in the approach. Beliefs have been described as "a complex set of variables based on attitudes, experiences and expectations" (Skinnari \& Bovellan, 2016, p. 146).

As a language of instruction, the CLIL approach uses a language that is not the children's first language or their mother tongue. Baïdak et al., (2006, p. 10) claim that the CLIL approach uses an additional or second language, which helps children learn. According to Eurydice (Content and Language Integrated Learning (CLIL) at School in Europe, 2006, p. 11), the additional languages can be English, German, French, Spanish or Russian - altogether, they represent $95 \%$ of all languages learnt by pupils in the EU. Georgiou (2012, p. 495-496) notes that "the CLIL approach is the highest developmental stage of communicative approach to language teaching". The CLIL approach allows pupils reasonable communication and at the same time provides them with an excellent opportunity to use a foreign language in an exercise. In this process, pupils can experience continuous learning, which is natural, unforced and thus more effective (Georgiou, 
2012, p. 495-496). It offers a highly scaffolded environment and the support to students in developing the skills needed for memorizing, describing, asking questions, cooperative group work, pair work, debating and so on for the assignments to be successful (Coyle et al., 2010). CLIL students have been shown to obtain greater oral communication, speaking fluency and social interaction skills in the foreign language, than students who only attend standard foreign language education (De Diezmaz, 2016; Dalton-Puffer, 2011; Mayo \& Ibarrola, 2014; Perez Canado, 2017; Arribas, 2016). Although CLIL is sometimes used as the term to exclusively refer to specific European bilingual education programmes using English as the language of instruction, CLIL shares the same essential characteristics as other Content-Based Instruction (CBI) programmes such as immersion programmes (Cenoz, 2015; Cenoz et al., 2013; Cenoz \& Ruiz de Zarobe, 2015). The CLIL approach creates a learning environment in which pupils acquire language skills through their immediate use and not in language lessons, where languages skills were acquired and developed for a future use.

\subsection{Background of the Research}

Considering the fact that the paper deals with teachers' attitudes, and to a certain extent belief, citing the monumental work of Krosnick and Perth (1995) is inevitable. It is assumed that there is a certain level of interchangeability of the terms attitude and belief and the following part will be dedicated to the teachers' beliefs. As Artner would put it (2016, p. 50) "the term 'belief' is easily understandable and readily used in day-to-day conversation. As a subject of research teachers' beliefs have developed from the 1940's onwards with an increased interest over the last 20 years." The author continues by stating that "some researchers see beliefs as something stable, unable to be changed, whereas others view them as dynamic." Both understandings are based on research findings and have influenced research and practice in equal measure (2016, p. 53).

Across the globe, the CLIL approach has proven to be timely and has been supported on all levels by all stakeholders, as Cross reported (2013). Particularly, in the state of Victoria, the authors claimed that "teachers reported even higher levels of support from content teachers by the end of the trial" (Cross, 2013, p. 69) on the one hand, while "principals expressed possible concern about how the approach had been perceived by the broader school community on the other hand." (Cross, 2013, p. 69). The discrepancy was reported by teachers related specifically to nonlanguage/content teachers with whom language teachers collaborated in developing the CLIL programme.

Cross also concluded that "CLIL has the potential to impact other curriculum areas. With immersion programs, the likelihood that it will impact other areas is very high, since at least 50\% of the curriculum is being delivered in the target language (Baker, 2006, as cited in Cross, 2013, p. 70; see also Gorjian \& Hamidavi, 2017). The authors pointed to an important consideration, that should a language teacher "attempt CLIL in an unsupportive school, and then have the program fail, will only reinforce existing negative perceptions/uncertainty about its potential. CLIL's success therefore ultimately depends on the quality of individual or small groups of teachers, working within supportive school environments." (Baker, 2006, as cited in Cross, 2013, p. 70-72; see also Gorjian \& Hamidavi, 2017). Studies have also revealed a great impact of CLIL on foreign language performance, content knowledge and also the impact on mother tongue, classroom interaction (Pastrana, Llinares \& Pascual, 2018), the influence of affective factors (Lasagabaster \& Doiz, 2015; Otwinowska \& Foryś, 2017), household structure (Mensel, Hilligsmann, Mettewie \& Galand, 2020), time and intensity (Surmont, et al., 2016; Merino \& Lasagabaster, 2017), age (Roquet, 2015), motivation (Fontecha \& Canga Alonso, 2014), gender (Canga Alonso, 2016; Fontecha \& Canga Alonso, 2014), strategies (Zarobe, 2017; Straková, 2020).

It is important to bring down language barriers and boost interest in English as a school subject (Rumlich, 2014). Researches in Japan, for example, mentioned "good points of CLIL" (Yamano, 2013; Ito, 2018a) through practices and investigations. Ito (2018b, p. 60) specifically highlighted the following: "students are less anxious about making mistakes in English as they are focused 
Vol. 4, No. 1, 2021, pp. 1-14

on lesson content; many students feel as though lessons are fun because their intellectual curiosity is fulfilled; and, many students feel that CLIL lessons are easy to understand as teachers tend to use visual aids.", thus bringing the CLIL approach's effectiveness to the sustainable level.

\section{Method}

\subsection{Research Problem, the Aim of the Research and Research Questions}

In the 2014/2015 school year, FL 1 pilot lessons were first carried out in the second grade of a state primary school, while all other state schools saw its initial introduction in the 2016/2017 school year. Teachers were asked to carry out FL 1 lessons according to the CLIL approach, which the school curriculum describes as a didactic recommendation, not as a compulsory approach to teaching (Pevec Semec et al., 2013). As a language of instruction, the CLIL approach uses a foreign language; however, according to constitutional provisions (Ustava Republike Slovenije, 1991), lessons in state schools cannot be carried out in a foreign language (except for the areas of autochthonous Italian and Hungarian national communities, where lessons in state schools are carried out in either Italian or Hungarian) (Ustava Republike Slovenije, 1991). We assumed that teachers had partly adopted their attitudes towards the introduction of FL 1 teaching according to the CLIL approach, which is why we wanted to investigate what they thought. We examined the teachers' attitude towards the introduction of FL 1 teaching according to the CLIL approach, their attitude towards foreign language learning and teaching according to the CLIL approach and their attitude towards the suitability of the CLIL approach in FL 1 lessons. Based on the aforementioned premises we aimed to determine whether the introduction of the CLIL approach changes the FL 1 teachers' attitude towards FL 1 learning and teaching in childhood. We also wanted to examine whether there are significant differences between FL 1 teachers' attitudes towards the suitability of the CLIL approach in FL 1 teaching. Lastly, we sought to find out whether there are significant differences in FL 1 teachers' attitude towards FL 1 learning and teaching in childhood and the CLIL approach with regard to gender, years of experience and acquired education of FL 1 teachers. See the Appendix for the list of questions for the semi-structured interview.

\subsection{Research Paradigm, Data Acquisition, Data Processing and Presentation of the Research Sample}

In the research, the qualitative research paradigm is used. The data were acquired by conducting semi-structured interviews, which allowed us to gain a detailed insight into the interviewees' attitudes. Ten interviews were carried out face-to-face, two by mail. The interviews were conducted in the period from 15. 2. 2016 to 31.3. 2016. The obtained material was processed and analysed using neither measurement process nor operations between numbers (Mesec, 1998). In the process of systematic coding of units obtained from the material, we formed theoretical explanations (Zhang \& Wildemuth, 2009).

The research sample was obtained by applying convenience sampling and as a result, 12 semistructured interviews with interviewees from all over Slovenia, except for its Central region, were carried out. There are no participants from the Central region of Slovenia, since none of the foreign language teachers whom we reached out to, had chosen to participate in our research. All 12 interviewees were female foreign language teachers at state elementary schools. Below is a detailed presentation of the sample.

Interviewee 1: female FL 1 class teacher with additional training in foreign language teaching methodology at an early age, 19 years of service and 8 years of teaching experience at an early age, born 1972.

Interviewee 2: female FL 1 class teacher with additional training in foreign language teaching methodology at an early age, 12 years of service, born 1988.

Interviewee 3: female FL 1 class teacher with additional training in foreign language teaching methodology at an early age, 26 years of service and 2 years of teaching experience at an early age, born 1963. 
Vol. 4, No. 1, 2021, pp. 1-14

Interviewee 4: female FL 1 class teacher with additional training in foreign language teaching methodology at an early age, 7 years of service and 2 years of teaching experience at an early age, born 1989.

Interviewee 5: female FL 1 class teacher with additional training in foreign language teaching methodology at an early age, 12 years of service, born 1984.

Interviewee 6: female FL 1 class teacher with additional training in foreign language teaching methodology at an early age, 8 years of service and 4 years of teaching experience at an early age, born 1986.

Interviewee 7: female FL 1 class teacher with additional training in foreign language teaching methodology at an early age, 10 years of service and 6 years of teaching experience at an early age, born 1983.

Interviewee 8: female FL 1 class teacher with additional training in foreign language teaching methodology at an early age, 10 years of service and 2 years of teaching experience at an early age, born 1981.

Interviewee 9: female FL 1 class teacher with additional training in foreign language teaching methodology at an early age, 13 years of service, born 1979.

Interviewee 10: female FL 1 class teacher with additional training in foreign language teaching methodology at an early age, 7 years of service, born 1983 .

Interviewee 11: female FL 1 class teacher with additional training in foreign language teaching methodology for the second cycle (classes 4 to 6 in the nine-grade Slovenian state elementary schools) of elementary schools, 10 years of service, born 1981.

Interviewee 12: female FL 1 and sociology teacher with additional training in foreign language teaching methodology at an early age, 17 years of service and 12 years of teaching experience at an early level, born 1973 .

\section{Findings and Discussion}

The results of the research are presented in individual categories that are derived from research questions. Some categories were combined with regard to the research questions.

\subsection{Category 1: The FL 1 Teachers' Attitude towards FL 1 Learning and Teaching in Childhood has Changed due to the Introduction of the CLIL Approach}

Most of the interviewees changed their attitudes during the introduction of the FL in the EP 1. We determined that most of the interviewees, who taught according to the CLIL approach at least for one year, only partly preserved the teaching methods according to this approach, as they observed that they can no longer strictly follow its teaching guidelines; consequently, they only used some of the elements or only the strategy of the CLIL approach in teaching. Interviewee 1, FL 1 teacher with 19 years of service, born 1972, stated: "I think that CLIL is still a very good approach, although I didn't often use it in the second year of the trial introduction, mostly due to a strict timetable and due to a different way of teaching." They preferred to adopt interdisciplinary integration strategies and some of them followed the guidelines set by the National Education Institute Slovenia in the second year of the introduction of the FL 1 in the EP 1, which recommend the use of the softer version of the CLIL approach. As would the Interviewee 5, FL 1 teacher with 12 years of service, born 1984, say: "The first year of the FL 1 trial introduction, 2013/2015, I had lots of support, CLIL was a recommended approach in the EP 1, but I later found out that I could not test the students' knowledge by using the traditional textbook approach, so now I mainly use cross-curricular links." As reasons for abandoning this approach, the interviewees stated different obstacles, from organizational problems (placement in the school schedule, remuneration for work, too large groups, combined lessons, etc.) to the particularity of modern generations of pupils. They also stressed the need to adapt their work to children's needs and establish a relationship with pupils. When asked about this, Interviewee 8, FL 1 teacher with 10 years of service, born 1981, 
said: "What matters is that you have a feeling for teaching children and the persons' character. A great factor at work is the personal touch." We can summarize that, due to the aforementioned problems, most of the interviewees do not apply the CLIL approach in foreign languages lessons in entirety, but only partly. Some of them did not adopt this approach because they felt themselves underqualified to carry out lessons using the CLIL approach, so they provided lessons using other approaches, of which interdisciplinary integration and the communication approach were the most commonly mentioned.

\subsection{Category 2: There are Differences in FL 1 Teachers' Attitude towards the Suitability of the CLIL Approach in FL 1 Teaching}

Three of twelve interviewees evaluated the CLIL approach as particularly suitable, whereas the others deemed it suitable in foreign language lessons, which are not carried out entirely in accordance with the CLIL approach due to several obstacles. As would Interviewee 11, FL 1 teacher with 10 years of service, born 1981 say: "Working according to CLIL is very demanding, your need to go through a lot of adjusting and cooperation with class teachers, which requires a lot of joint planning, exchange of materials and sources." This approach was applied by some interviewees from time to time and on occasions where this was reasonable, while others used it all the time. Some interviewees mentioned the use of the CLIL matrix, which was used in the second year of the introduction of the FL 1 in foreign language lessons, while others were aware of the suitability of the CLIL approach for carrying out foreign language lessons, yet they preferred to use interdisciplinary integration and learning approaches similar to the CLIL approach in that same period. To sum up, we perceived much insecurity regarding what expectations the experts formulating language policies set up about the FL 1 teachers in the EP 1, what type of the CLIL approach the FL 1 teachers were supposed to adopt with children at an early age, where they could get qualified for this type of work and whether they would be remunerated for the additional work that they do. Some interviewees claimed that they were prepared to provide FL 1 lessons in accordance with the CLIL approach if they could acquire the appropriate qualification, since they had a positive attitude towards this approach. When directly asked about the suitability of the CLIL approach in FL 1 teaching, Interviewee 2, FL 1 teacher with 12 years of service, born 1988, said: "If I understand CLIL correctly, strictly speaking, it's not useful, because I have to teach my kids the names of the objects in their mother tongue first. Some elements are ok, for example the communication." Interviewee 3, FL 1 teacher with 26 years of service, born 1963 added: "I think CLIL is not useful, its elements are, though, but not the whole. So, not the whole, just at times and occasionally, where it's possible and feasible."

\subsection{Category 3: There are Differences in the FL 1 Teachers' Attitude towards FL 1 Learning and Teaching in Childhood and towards the CLIL Approach with Regard to Gender, Years of Experience and the Acquired Education of FL 1 Teachers}

The interviewees all agreed upon the importance of the acquired education of FL 1 teachers in the EP 1, who should have completed a BA in class teaching and acquired a degree in the methodology of early English/German teaching. According to the interviewees, teachers with such education are suitable for this type of work, as they are the most familiar with teaching approaches and methods used with children at an early age. Some interviewees stressed the importance of a relationship established by teachers with younger pupils. Interviewee 3, FL 1 teacher with 26 years of service, born 1963 believed that "this depends on the personality, on how teachers can approach children". The interviewees thought it better for class teachers to carry out lessons with younger pupils, as they are more familiar with the children's needs and the school curriculum for this period, they find it easier to follow teaching guidelines and they know the teaching didactics appropriate for children at an early age. Three interviewees, who recognized years of experience as an important factor, stressed that teachers teaching FL 1 in the EP 1 should have more experience. Following up the last statement, Interviewee 9, FL 1 teacher with 13 years of service, born 1979 stated that "a teacher with more years of experience has more knowledge on the characteristics of younger pupils and more authority over them". Interviewee 11, FL 1 teacher with 10 years of service, born 1981 believed that "years of experience bring more 
confidence". In addition to the importance of years of experience, Interviewee 12, FL 1 teacher with 17 years of service, born 1973 stressed that "years of experience are fairly decisive, but they are not the most important factor. If a teacher with many years of experience refrains from trying something new or does not follow new didactic recommendations and techniques, years of experience can only be a burden /.../. Younger teachers have an advantage in this field but lack broader knowledge." To summarize, approximately a half of the interviewees agree with the statement that years of experience in carrying out FL 1 lessons for children in the EP 1 have an important role; nonetheless, they also stress the importance of teachers' personality, the willingness to introduce changes in how to carry out lessons and the awareness of the particularity of younger pupils.

In the research, all the interviewees stated that the CLIL approach would be more suitable for providing lessons with older pupils from the EP 2 or 3: "The CLIL approach is more suitable in the EP 2, if not even in the EP 3, for pupils have enough foreign language competencies" (Interviewee 4). However, Coyle et al., (2010, p. 4) stress this exact aspect of the CLIL approach: neither a language lesson nor a non-language lesson, but a combination of both. This approach merges what looks like fragments at first glance, such as independent school subjects, into one comprehensive learning experience (Coyle et al., 2010).

Some interviewees in our research often mentioned the problems that arose when they tried to introduce the CLIL approach in the FL 1 lessons. The most frequent problems were of organizational nature (placement of a foreign language lesson in the school schedule, compliance with the EP 1 school curriculum, lack of time for coordination with class teachers, lack of understanding by the school management and other staff, remuneration for work). Some teachers did not quite grasp the aim of the CLIL approach, they misplaced their attention to language and misregarded their awareness regarding the integration of language and content, which is the aim of CLIL programmes. As Lazarević (2019, p. 8) reported in a study conducted on high school teachers in Serbia, "teachers did not consider organizing instruction differently for their CLIL classes". These problems could be the result of distress experienced by the said interviewees because the expectations towards the FL 1 class conducting in accordance with the principles of the CLIL approach in the first year of its introduction were very high. Only two of 12 interviewees had used the CLIL approach or approaches similar to the CLIL approach for a long time directly before its formal introduction in the FL 1 lessons. Some have even considered abandoning entirely the use of the CLIL approach. Cammarata (2009) emphasizes that the use of the CLIL approach partly re-establishes the teachers' identity as such, for the CLIL approach makes teachers question their self-beliefs as professionals in a certain field. This can lead to a crisis and the abandonment of the CLIL approach, as was reported by the interviewees and as is noted by Cammarata (2009). The reasons for abandoning the CLIL approach can also be found in the perceived lack of participation between FL 1 teachers, their co-workers and other parties. Another reason for abandoning CLIL in the difficulty of integrating content and language, which ahs been the core of many of the problems FL teachers had to face and is also reported in many studies (Cammarata \& Tedick, 2012; Koopman et al., 2014; Oattes et al., 2018). Moreover, according to Cammarata $(2009,2010)$, the abandonment of this approach can be a result of the lack of control in the CLIL lessons planning process, pressure from evaluation and the excessive emphasis that teachers are responsible for the pupils' progress. This means that most of the participants in the qualitative part of the research had been made aware of the CLIL approach before the introduction of the FL 1 in the second grade or even during this process. At the same time, this indicates that we talk about the profile of a classical FL 1 teacher whom the CLIL approach appeared unfamiliar or mostly unfamiliar. On the other hand, the CLIL approach and approaches similar to the CLIL approach stress the significance of extraordinary possibilities for professional development of teachers (European Commission, 2017), as this approach presents some sort of a challenge that makes them rethink and reshape their own practice methods as well as consider their own professional integrity, which is discussed in the works by Cammarata (2009), Viebrock (2009) and Moate (2011). The interviewees participating in our research reported on similar experience; 
considering they had mostly had no experience in teaching according to the CLIL approach, they faced a great challenge in the first year of its introduction (2014/2015). They were aware that teachers applying the CLIL approach must have special knowledge in the field of language competence as well as teaching and methodological skills and thorough knowledge of the nonlanguage subject to be taught (Content and Language Integrated Learning (CLIL) at School in Europe, 2006). It has also been revealed that teachers in CLIL contexts seem to struggle to focus on language and content at the same time and find it challenging to know how to focus on language (Cammarata \& Tedick, 2012; Costa, 2012: Goris et al., 2019).

The interviewees expressed the fear that they are not qualified enough to apply the CLIL approach and that they do not use this approach due to the lack of its skilful application. This is not surprising as most of the interviewees had more than five years of experience, while the CLIL approach was not a widely used approach in Slovenia in that period, except for some minor projects (for example, at the Bojan Ilich Primary School (Jazbec \& Lovrin, 2015, p. 70), at the Manko Golar Kindergarten in Gornja Radgona, at the Josip Vandot Kindergarten and Primary School in Kranjska Gora, and elsewhere). Moreover, the CLIL approach and approaches similar to the CLIL approach were regularly applied in FL 1 lessons by only two of 12 interviewees. The problem behind effective application and use of the CLIL approach probably lies in the fact that most teachers, who apply the CLIL approach to FL 1 lessons, are either language teachers (of English or German) or have completed a BA in class teaching and acquired a degree in the methodology of early language teaching. This can be challenging for teachers as they have to obtain adequate skills in either a foreign language or in the field to be taught with the help of a foreign/additional language; teachers must be able to regulate their knowledge of the subject and the language (Cammarata \& Tedick, 2012). In order to make the transition into the full CLIL lesson smoother, FL teachers might consider to have a content teacher and a language teacher working together in the class (Méndez García \& Pavón Vázquez, 2012; Pavón Vázquez \& Ramos Ordóñez, 2018), although that is no common. Some of the teachers also reported having problems with form and could focus on language pedagogies that would direct their attention to this issue (Gierlinger, 2017; He \& Lin, 2018; Lo, 2019). This indicates that teachers must acquire skills that encourage the formulation of supporting strategies for foreign language teaching (Boutin, 1993). Inspite of all the setbacks and difficulties most FL teachers still deem CLIL to be a suitable approach in language teaching in the early age (Anderson, McDougald \& Cuesta Medina, 2015; Griva \& Kasvikis, 2014; Pfenninger, 2016).

There are also other considerations. Nikula (2016) claims that while research has provided a sound evidence base for the effects of CLIL on language learning, there are doubts regarding the CLIL approach's fitness for all types of learners. The author also raises another question, namely the question of equity, is the CLIL approach suitable for students with learning difficulties and also, the fact that availability of CLIL programmes tends to concentrate in bigger towns and municipalities has raised concerns about CLIL compromising equity (Nikula \& Järvinen, 2013). This has been a particularly felt issue among the interviewees, since many came from small communities with little support from neither their school authorities nor from their peers in school or from the National Board of Education. On the other hand, Suhandoko (2019) reported positive attitudes of the English teacher regarding the use of CLIL approach, which results sustainable. The examination of foreign language lessons in accordance with the CLIL approach will probably need more attention in the future and as Wei and Feng $(2015$, p. 60) would put it" that the benefits of CLIL programmes for young learners can only be maximized when people's language practices, beliefs and the authorities' management are consistent with each other", which is exactly the reason why the majority of FL teachers included in our research stated that they would continue using the CLIL approach in their EFL class (Smajla, 2019). Moreover, considering the pragmatic nature of CLIL it will be crucial for FL teachers to continue developing their skills, the "so called soft skills", which are as much pivotal for them as for their students (Moraleja Novillo, 2018, p. 18). It is also, as Pérez Cañado (2021, p. 31) put it "an uncontested fact that we are living in times of profound change in English language teaching", hence all the FL teachers should 
rethink their teaching approaches and find a set of those who cater for the most of their students' needs, since it is them who will eventually prepare them "for authentic international/intercultural communication (Vettorel \& Corrizzatto, 2016, p. 503). It has also been established that teacher educators should, and that goes for the National Board of Education as well, in order not to be considered illiterate of the twenty-first century", make themselves willing to learn, unlearn and relearn" (Siqueira, 2017, p. 400).

\section{Conclusion}

The research results have revealed the undisputed usefulness and suitability of the CLIL approach in FL teaching. It has been established that the FL teachers must also be aware that lesson planning strategies have to be revised. The same goes for educational authorities and teacher educators. The urge to develop a new teacher development paradigm has to be put into place and into practice, one that would include relevant premises, practices, conceptions, strategies and tools that are in their core very diverse form the ones teacher educators have been utilizing so far. FL teachers' main goal should remain the focus on constant and lifelong participative learning and cooperation with their peers. They should keep up their motivation to bring innovation into the FL teaching and think outside the box. All too often quitting the safety zone is not an option for many a teacher, yet new circumstances in and outside of FL teaching, in the community and their organization may force many FL teachers to tackle the difficult task of unlearning the old ways and relearning some new approaches.

Declaration

\section{REFERENCES}

Anderson, C. E., McDougald, J. S. in Cuesta Medina, L. (2015). CLIL for young learners. In C. N. Giannikas, L. McLaughlin, G. Fanning and N. D. Muller (Eds), Children learning English: From Research to Practice (pp. 137152). Garnet Education. Available at: https://blog.ufes.br/kyriafinardi/files/2017/10/CLIL-for-Young-Learners.pdf (accessed May 4 2019).

Arribas, M. (2016). Analyzing a whole CLIL school: students attitudes, motivation, and receptive vocabulary outcomes. Latin American Journal of Content \& Language Integrated Learning 9(2): $267-$ 292.

Artner, S. (2016). Pre-service and in-service teacher beliefs about content and language integrated learning (CLIL) in physical education (PE) in Austria (Doctoral dissertation, uniwien). doi: $10.25365 /$ thesis. 42360

Baïdak, N., García Mínguez, M.L., \& Oberheidt, S. (2006). Eurydice. Content and Language Integrated Learning (CLIL) at Schools in Europe. Brussels: European Commission. Available at: https://www.indire.it/lucabas/lkmw_file/eurydice/CLIL_EN.pdf (accessed 18 January 2021).

Baker, C. (2011). Foundations of bilingual education and bilingualism. Britstol: Multilingual matters.

Boutin, F. (1993). A study of early French immersion teachers as generators of knowledge. Foreign Language Annals, 26(4), 511-525. https://doi.org/10.1111/j.1944-9720.1993.tb01184.x 
Cammarata, L. (2009). Negotiating curricular transitions: Foreign language teachers' learning experience with content-based instruction. Canadian Modern Language Review, 65(4), 559-585. https://doi.org/10.3138/cmlr.65.4.559

Cammarata, L., \& Tedick, D.J. (2012). Balancing content and language in instructing: The experience of immersion teachers. The Modern Language Journal 96(2): 251-296. https://doi.org/10.1111/j.15404781.2012.01330.x

Canga Alonso A (2013). The receptive vocabulary of Spanish 6th-grade primary school students in CLIL instruction: A preliminary study. Latin American Journal of Content and Language Integrated Learning 6(2): 22-41. https://doi.org/10.5294/laclil.2013.6.2.2

Cenoz, J. (2015). Content-based instruction and content and language integrated learning: The same or different? Language, Culture \& Curriculum 28(1): 8-24. https://doi.org/10.1080/07908318.2014.1000922

Cenoz, J., Genesee, F., \& Gorter, D. (2013). Critical analysis of CLIL: Taking stock and looking forward. Applied Linguistics 35(3): 243-262. https://doi.org/10.1093/applin/amt011

Cenoz, J., \& Ruiz de Zarobe, Y. (2015). Learning through a second or additional language: Content based instruction and CLIL in the 21st century: An introduction. Language, Culture and Curriculum 28(1): 17. https://doi.org/10.1080/07908318.2014.1000921

Content and Language Integrated Learning (CLIL) at School in Europe (2006). Brussels: European Commission. Available at: http://bookshop.europa.eu/en/content-and-language-integrated-learningclic-at-school-in-europe-pbNCX106001/ (accessed 18 January 2021).

Costa, F. (2012). Focus on form in ICLHE lectures in Italy: Evidence from English-medium science lectures by native speakers of Italian. AILA Review 25, 30-47. https://doi.org/10.1075/aila.25.03cos

Council Resolution of 31 March 1995 on improving and diversifying language learning and teaching within the education systems of the European Union. (1995). Brussels: Publications Office of the European Union. Available at: https://op.europa.eu/en/publication-detail/-/publication/2f401f44-afaa-424c-a85ecbf8ee3cb251/language-en (accessed 18 January 2021).

Coyle. D., Hood, P., and Marsh D .(2010). CLIL: Content and Language Integrated Learning. Cambridge: Cambridge University Press.

Cross, R. (2013). Research and evaluation of the content and language integrated learning (CLIL) approach to teaching and learning languages in Victorian schools. Victorian Department of Education and Early Childhood. Retrieved from: http://hdl.handle.net/11343/55778

Cummins J (2000) Language, power and pedagogy. Clevendon: Multilingual Matters. https://doi.org/10.21832/9781853596773

Čok, L. (2008). Zgodnje učenje jezikov v povezavi s celostnim razvojem otroka. In: J. Skela (Ed) Učenje in poučevanje tujih jezikov na Slovenskem. Pregled sodobne teorije in prakse. Ljubljana: Tangram, pp. $18 \neg 29$.

Dagarin Fojkar, M., \& Skubic, D. (2017). Prepričanja študentov predšolske vzgoje o učenju in zgodnjem poučevanju tujega jezika v Sloveniji. CEPS Journal 7(4): 85-104. Retrieved from: http://pefprints.pef.uni-lj.si/id/eprint/4966

Dalton-Puffer, C. (2011). Content and language integrated learning: from practice to principles? Annual Review of Applied Linguistics 31: 182-204. https://doi.org/10.1017/S0267190511000092

De Diezmas, E. M. N. (2016). The impact of CLIL on the acquisition of language competencies and skills in L2 in primary education. International Journal of English Studies 16(2). https://doi.org/10.6018/ijes/2016/2/239611

European Commission (2017) Key data on teaching languages at school in Europe - 2017 edition. Available at: https://eacea.ec.europa.eu/national-policies/eurydice/content/key-data-teaching-languages-schooleurope--2017-edition_en (accessed 18 January 2021).

Fontecha, A. F., \& Canga Alonso, A. (2014). A preliminary study on motivation and gender in CLIC and non- CLIL types of instruction. International Journal of English Studies 14(1): 21-36. https://doi.org/10.6018/ijes/14/1/156681

Gierlinger, E. M. (2017). Teaching CLIL? Yes, but with a pinch of salt. Journal of Immersion and ContentBased Language Education 5(2): 187-213. https://doi.org/10.1075/jicb.5.2.02gie 
Vol. 4, No. 1, 2021, pp. 1-14

Gorjian, B., \& Hamidavi, N. (2017). Using CLIL method in teaching vocabulary to intermediate EFL learners. Modern Journal of Language Teaching Methods 7(3): 13-23.

Goris, J., Denessen, E., \& Verhoeven, L. (2019). Effects of content and language integrated learning in Europe A systematic review of longitudinal experimental studies. European Educational Research Journal 18(6): 675-698. https://doi.org/10.1177/1474904119872426

Griva, E., \& Kasvikis, K. (in press, 2014). CLIL in primary education: Possibilities and challenges for developing L2/FL skills, history understanding and cultural awareness. In N. Bakić-Mirić and D. Erkinovich Gaipov (Eds), Current trends and issues in education: an international dialogue. Cambridge: Cambridge Scholars Publishing. Available at: https://enl.auth.gr/gala/pubs/files/1_Griva\&Kasvikis.pdf (accessed May 4 2019).

He, P., \& Lin, A. (2018). Becoming a "language-aware" content teacher: Content and Language Integrated Learning (CLIL) teacher professional development as a collaborative, dynamic, and dialogic process. Journal of Immersion and Content-Based Language Education 6(2): 162-188. https://doi.org/10.1075/jicb.17009.he

Georgiou, I.S., (2012) Reviewing the puzzle of CLIL. ELT Journal, Special Issue, 66(4): 495-496. https://doi.org/10.1093/elt/ccs047

Ito, Y. (2018a). Kankakukikan to umamino CLIL (naiyougengo tougougata gakushuu) wo tooshite erareru shou/ chuugakusei no ibunka ni taisuru manabi ni tsuite no kousatu [a study of cross-cultural learning patterns within elementary school and junior high school students through CLIL on the sensory organs and umami.]. Osaka-Kyoiku University. Shotou kyouiku kouza jissen gakkou kyouiku kenkyuu, 20: 918.

Ito, Y. (2018b). CLIL in practice in Japanese elementary classrooms: An analysis of the effectiveness of a CLIL lesson in Japanese traditional crafts. English Language Teaching; 11(9): 59-67. https://doi.org/10.5539/elt.v11n9p59

Jazbec, S., \& Lovrin M. (2015). Koncept CLIL - novost ali stalnica pri učiteljih na OŠ v Sloveniji. Journal of Elementary Education, 8(1/2), 65-80. Retrieved from https://journals.um.si/index.php/education/article/view/416

Karabassova, L. (2018). Teachers' conceptualization of content and language integrated learning (CLIL): Evidence from a trilingual context. International Journal of Bilingual Education and Bilingualism 1 13. https://doi.org/10.1080/13670050.2018.1550048

King, K. A., \& Mackey, A. (2007). The bilingual edge: Why, when, and how to teach your child a second language. New York: Collins. Retrieved from http://languageonthemove.com/downloads/PDF/king_mackey\%20preprint.pdf

Koopman, G. J., Skeet, J., \& de Graaff, R, (2014). Exploring content teachers' knowledge of language pedagogy: A report on a small-scale research project in a Dutch CLIL context. Language Learning Journal 42(2): 123-136. https://doi.org/10.1080/09571736.2014.889974

Kovalik, S., \& Olsen, K. (1993). ITI: The model: Integrated thematic instruction. Alaska: S. Kovalik \& Associates.

Krosnick, J. A. \& Perth, R.E. (eds) (1995) Attitude strength: Antecedent and consequences. New York: Lawrence Erlbaum Associates, Inc.

Lasagabaster, D., \& Doiz, A. (2015). A longitudinal study on the impact of CLIL on affective factors. Applied Linguistics. https://doi.org/10.1093/applin/amv059

Lazarević, N. (2019) CLIL teachers' reflections and attitudes: Surviving at the deep end. International Journal of Bilingual Education and Bilingualism 1-14. https://doi.org/10.1080/13670050.2019.1703897

Llinares, A., \& Morton, T (eds). (2017). Applied linguistics perspectives on CLIL. Netherlands: John Benjamins Publishing Company. https://doi.org/10.1075/11lt.47

Lipavic Oštir A and Lipovec A. (2018). Problemorientierter soft CLIL ansatz. Wina: LIT Verlag.

Lipavic Oštir A., Lipovec A., \& Rajšp M. (2015). CLIL - orodje za izbiro nejezikovnih vsebin . Journal of Elementary Education, 8(1/2), 11-26. Retrieved from https://journals.um.si/index.php/education/article/view/413

Lo, Y. Y. (2019). Development of the beliefs and language awareness of content subject teachers in CLIL: Does professional development help? International Journal of Bilingual Education and Bilingualism 
22(7): 818-832. https://doi.org/10.1080/13670050.2017.1318821

Mayo García, del Pilar María and Lázaro-Ibarrola Amparo. (2014). Do children negotiate for meaning in task-based interaction? Evidence from CLIL and EFL settings. System 54: 40-54. https://doi.org/10.1016/j.system.2014.12.001

Méndez García, M. C., \& Pavón Vázquez, V. (2012). Investigating the coexistence of the mother tongue and the foreign language through teacher collaboration in CLIL contexts: Perceptions and practice of the teachers involved in the plurilingual programme in Andalusia. International Journal of Bilingual Education and Bilingualism 15(5): 573-592. https://doi.org/10.1080/13670050.2012.670195

Merino, J. A., \& Lasagabaster, D. (2017). The effect of content and language integrated learning programmes' intensity on English proficiency: A longitudinal study. International Journal of Applied Linguistics 28(1): 18-30. https://doi.org/10.1111/ijal.12177

Mensel, L. V., Hiligsmann, P., Mettewie, L., \& Galand, B. (2020). CLIL, an elitist language learning approach? A background analysis of English and Dutch CLIL pupils in French-speaking Belgium. Language, Culture and Curriculum 33(1): 1-14. https://doi.org/10.1080/07908318.2019.1571078

Mesec, B. (1998). Uvod v kvalitativno raziskovanje v socialnem delu. Ljubljana: Visoka šola za socialno delo.

Moate, J. M. (2011). The impact of foreign language mediated teaching on teachers' sense of professional integrity in the CLIL classroom. European Journal of Teacher Education 34(3): 333-346. https://doi.org/10.1080/02619768.2011.585023

Moraleja Novillo, S. (2018). Educar el talento: Guía para desarrollar nuevas habilidades en jóvenes y niños. Barcelona: Editorial AMAT.

Nikula, T., \& Järvinen, H. M. (2013). Vieraskielinen opetus Suomessa ('CLIL in Finland'). In L. Tainio and H. Harju-Luukkanen (Eds), Kaksikielinen koulu- tulevaisuuden monikielinen Suomi ('Bilingual school - the multilingual Finland of the future') (pp. 143-167). Helsinki: Suomen Kasvatustieteellinen Seura.

Nikula, T. (2016). CLIL: A European approach to bilingual education. In N. V. Deusen-Scholl, \& S. May (Eds), Second and foreign language education (pp. 1-14). Springer International Publishing. https://doi.org/10.1007/978-3-319-02323-6_10-1

Nikula, T., Dafouz, E., Moore, P., \& Smit, U (eds). (2016). Conceptualising integration in CLIL and multilingual education. Multilingual Matters. https://doi.org/10.21832/9781783096145

Oattes, H., Oostdam, R., de Graaff, R., \& Wilschut, A. (2018). The challenge of balancing content and language: Perceptions of Dutch bilingual education history teachers. Teaching and Teacher Education 70: 165-174. https://doi.org/10.1016/j.tate.2017.11.022

Ortega, L. (2015). Researching CLIL and TBLT interfaces. System 54, 103-109. https://doi.org/10.1016/j.system.2015.09.002

Otwinowska, A., \& Foryś, M. (2015). They learn the CLIL way, but do they like it? Affectivity and cognition in upper-primary CLIL classes. International Journal of Bilingual Education and Bilingualism 20(5): 457-480. https://doi.org/10.1080/13670050.2015.1051944

Pastrana, A., Llinares, A., \& Pascual, I. (2017). Students' language use for coconstruction of knowledge in CLIL group-work activities: A comparison with L1 settings. Zeitschrift Für Erziehungswissenschaft 21(1): 49-70. https://doi.org/10.1007/s11618-017-0802-y

Pavón Vázquez, V., \& Ramos Ordóñez, M. C. (2018). Describing the use of the L1 in CLIL: An analysis of L1 communication strategies in classroom interaction. International Journal of Bilingual Education and Bilingualism 22(1): 35-48. https://doi.org/10.1080/13670050.2018.1511681

Pérez Cañado, M. L. (ed) (2021). CLIL and ELF: Friends or Foes? In: M L Pérez Cañado (ed) Content and Langauge Integrated Learning in Monolingual Settings, (pp. 31 53 ). Multilingual Education 38. Springer Nature Switzerland AG. https://doi.org/10.1007/978-3-030-68329-0

Pérez Cañado, M. L. (2017). The effects of CLIL on L1 and content learning: Updated empirical evidence from monolingual contexts. Learning and Instruction. 57: 18ᄀ33. https://doi.org/10.1016/j.learninstruc.2017.12.002

Pérez Vidal, C., \& Roquet, H. (2015). CLIL in context: Profiling language abilities. Content-based Language Learning in Multilingual Educational Environments (pp.237-255). https://doi.org/10.1007/978-3-319-11496-5_14 
Vol. 4, No. 1, 2021, pp. 1-14

Pevec Semec, K, Kač L Šečerov N Cajhen S Lesničar B Lipavic Oštir A and Strmčnik L. (2013). Učni načrt za drugi tuji jezik kot neobvezni izbirni predmet v osnovni šoli. [Curriculum of Foreign Language Teaching and learning in 2nd and 3rd grade]. Ljubljana: Zavod RS za šolstvo. Available at: http://www.mizs.gov.si/fileadmin/mizs.gov.si/pageuploads/podrocje/ os/devetletka/program_razsirjeni/Drugi_TJ_izbirni_neobvezni.pdf (accessed 18 January 2021).

Pevec Semec K, Kač L Šečerov N Cajhen S Lesničar B Lipavic Oštir A, \& Strmčnik L. (2013). Učni načrt. Program osnovna šola. Drugi tuji jezik v 4. do 9. Razredu: neobvezni izbirni predmet. [Curriculum of Foreign Language Teaching and learning from4th to 9th grade]. Ljubljana: Ministrstvo za izobraževanje, znanost in šport, Zavod Republike Slovenije za šolstvo Retrieved from http://www.fmalgaja.si/files/2017/05/Drugi_TJ_izbirni_neobvezni.pdf (accessed 18 January 2021).

Pfenninger, S. E. (2016). All good things come in threes: Early English learning, CLIL and motivation in Switzerland. Cahiers de l'ILSL, 48, 119ᄀ147.

Rumlich, D. (2014). Prospective CLIL and non-CLIL students interest in English (classes): A quasiexperimental study on German sixth-graders. Utrecht Studies in Language and Communication 28 : $75 \neg 95$.

Siqueira, S. (2017). Intercultural language educators for an intercultural world: Action upon reflection. Intercultural Education 28(4): 390-407. https://doi.org/10.1080/14675986.2017.1334396

Skinnari, K., \& Bovellan, E. (2016). CLIL teachers' beliefs about integration and about their professional roles: Perspectives from a European context. In T Nikula, E Dafouz, P Moore, and U Smit (eds), Conceptualising integration in CLIL and multilingual education (pp. 145-167). Multilingual Matters. https://doi.org/10.21832/9781783096145-010

Smajla, T. (2019). Odnos do uvajanja vsebinsko in jezikovno integriranega učenja tujega jezika v zgodnjem obdobju. [Attitudes toward the introduction of content and language integrated learning at an early age.] (Doctoral Thesis). Koper: Univerza na Primorskem,

Straková, Z. (2020). CLIL and global education: A meaningful match. Society. Integration. Education. Proceedings of the International Scientific Conference 5: 546-557. https://doi.org/10.17770/sie2020vol5.4819

Suhandoko. (2019). CLIL-oriented and task-based EFL materials development. ELT Worldwide 6(2): 144162. https://doi.org/10.26858/eltww.v6i2.10662

Surmont, J., Struys, E., Noort., M. V., \& Craen, P. V. (2016). The effects of CLIL on mathematical content learning: A longitudinal study. Studies in Second Language Learning and Teaching 6(2): 319-337. https://doi.org/10.14746/ssllt.2016.6.2.7

Taillefer, G. (2013). CLIL in higher education: The (perfect?) crossroads of ESP and didactic reflection. ASp (63): 31-53. https://doi.org/10.4000/asp.3290

Tzoannopoulou, M. (2015). Rethinking ESP: Integrating content and language in the university classroom. Procedia - Social and Behavioral Sciences 173: 149- 153. https://doi.org/10.1016/j.sbspro.2015.02.045

Ustava Republike Slovenije /URS/ [The Constitution of the Republic of Slovenia] (1991) Uradni list RS, št. 75 (23. 12. 1991). Available at: http://pisrs.si/Pis.web/pregledPredpisa?id=USTA1 (accessed 18 January 2021).

Van Mensel, L., Hiligsmann, P., Mettewie, L., \& Galand, B. (2020). CLIL, an elitist language learning approach? A background analysis of English and Dutch CLIL pupils in French-speaking Belgium. Language, Culture and Curriculum 33(1): 1-14. https://doi.org/10.1080/07908318.2019.1571078

Vettorel, P., \& Corrizzato, S. (2016). Fostering awareness of the pedagogical implications of worlds Englishes and ELF in teacher education in Italy. Studies in Second Language Learning and Teaching 6(3): 487-511. https://doi.org/10.14746/ss1lt.2016.6.3.6

Viebrock, H. J. (2009). Bilingualer erdkundeunterricht. subjektive didaktische theorien von lehrerinnen und lehrern. Frankfurt: Peter Lang.

Wei, R., \& Feng, J. (2015). Implementing CLIL for young learners in an EFL context beyond. English Today 31(1): 55-60. https://doi.org/10.1017/S0266078414000558

Yamano, Y. (2013). CLIL in a Japanese primary school: Exploring the potential of CLIL in a Japanese EFL context. International CLIL Research Journal, 2 (1), 19-30. Retrieved from http://www.icrj.eu/21/article2.html

Zarobe Y R (2017) Improving reading strategy knowledge in young children: What self-report 
Vol. 4, No. 1, 2021, pp. 1-14

questionnaires can reveal. Estudios de Lingüística Inglesa Aplicada (17): 15-45. https://doi.org/10.12795/elia.2017.i17.02

Zhang, Y., \& Wildemuth, B.M. (2009) Qualitative analysis of content. In: B M Wildemuth (ed) Applications of Social Research Methods to Questions in Information and Library Science (pp. 308ᄀ319.) Westport: Libraries Unlimited.

\section{Supplementary Material}

List of questions for the semi-structured interview:

1. What is your attitude towards the teaching and learning of a foreign language at an early age?

2. What is your attitude towards the CLIL approach?

3. What is your attitude towards the teaching and learning of a foreign language and towards the CLIL approach regarding the gender, years of service, and education level of the foreign language teacher?

4. Have your attitudes changed and why?

5. How suitable is the CLIL approach in foreign language teaching? 